\title{
"The impact of state regulation in a sphere of education on sustainable development of national economy"
}

\author{
Anna Vorontsova (D https://orcid.org/0000-0003-0603-3869 \\ R http://www.researcherid.com/rid/R-3313-2018 \\ Hanna Shvindina iD https://orcid.org/0000-0003-0883-8361 \\ R http://www.researcherid.com/rid/B-4494-2018 \\ AUTHORS \\ Tetyana Mayboroda (D https://orcid.org/0000-0002-4547-5822 \\ Halyna Mishenina iD http://orcid.org/0000-0003-4366-1864 \\ R http://www.researcherid.com/rid/R-2438-2018 \\ Iryna Heiets (D https://orcid.org/0000-0003-1267-3790 \\ R http://www.researcherid.com/rid/Q-7689-2018
}

Anna Vorontsova, Hanna Shvindina, Tetyana Mayboroda, Halyna Mishenina and

ARTICLE INFO Iryna Heiets (2020). The impact of state regulation in a sphere of education on sustainable development of national economy. Problems and Perspectives in Management, 18(4), 275-288. doi:10.21511/ppm.18(4).2020.23

DOI http://dx.doi.org/10.21511/ppm.18(4).2020.23

RELEASED ON Monday, 14 December 2020

RECEIVED ON Tuesday, 29 September 2020

ACCEPTED ON Friday, 04 December 2020

(cc) EY

LICENSE

This work is licensed under a Creative Commons Attribution 4.0 International License

JOURNAL

"Problems and Perspectives in Management"

ISSN PRINT $1727-7051$

ISSN ONLINE $1810-5467$

PUBLISHER

LLC "Consulting Publishing Company "Business Perspectives"

FOUNDER

LLC "Consulting Publishing Company "Business Perspectives"

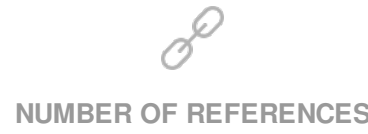

77
NUMBER OF FIGURES

2
NUMBER OF TABLES

5

(C) The author(s) 2021. This publication is an open access article. 


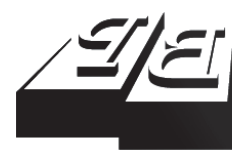

BUSINESS PERSPECTIVES

(2)

LLC "CPC "Business Perspectives"

Hryhorii Skovoroda lane, 10,

Sumy, 40022, Ukraine

www.businessperspectives.org

Received on: $29^{\text {th }}$ of September, 2020 Accepted on: $4^{\text {th }}$ of December, 2020

Published on: $14^{\text {th }}$ of December, 2020

(c) Anna Vorontsova, Hanna Shvindina, Tetyana Mayboroda, Halyna

Mishenina, Iryna Heiets, 2020

Anna Vorontsova, Ph.D., International Economic Relations Department, Sumy State University, Ukraine.

Hanna Shvindina, Doctor of Science, Associate Professor, Department of Management, Sumy State University, Ukraine. (Corresponding author)

Tetyana Mayboroda, Ph.D., Department of Management, Sumy State University, Ukraine.

Halyna Mishenina, Ph.D., Associate Professor, Department of Management, Sumy State University, Ukraine.

Iryna Heiets, Ph.D., Associate Professor, School of Engineering, Department of Aerospace Engineering and Aviation, RMIT University, Australia.
Anna Vorontsova (Ukraine), Hanna Shvindina (Ukraine), Tetyana Mayboroda (Ukraine), Halyna Mishenina (Ukraine), Iryna Heiets (Australia)

\section{THE IMPACT OF STATE REGULATION IN A SPHERE OF EDUCATION ON SUSTAINABLE DEVELOPMENT OF NATIONAL ECONOMY}

\begin{abstract}
Education is a core element of the Sustainable Development Concept. It is not only because of the declaration of SDG 4 within the 2030 Agenda but also its embeddedness in other goals, targets, and indicators. Thus, the study aims to generalize approaches to define the relationship between the efficiency of the strategy of sustainable development of the national economy and state regulation of education. The research is accomplished for 14 Central and Eastern European countries (2006-2016) using the combination of principal components method and parametric method of stochastic frontier analysis in the software package STATA 11 and FRONTIER 4.1. As a result, the empirical proofs of the strong and adequate link between the efficiency of the sustainable development strategy of the national economy and state regulation of education are identified. The technical efficiency indexes were also calculated that allowed forming three clusters for Central and Eastern European countries distributed by the level of state regulation of education and efficiency of sustainable development strategy implementation. It helps to distinguish the main measures to reform the state regulation of education in Ukraine considering the experience of Slovenia, Poland, the Czech Republic, countries that proved to be the leaders in a sphere of sustainable development strategy implementation. The recommendations for further improvements in educational policies were defined. For instance, effective and sustainable state regulation of education should focus on decentralizing education, developing private-public partnerships, stimulating adult education development, etc.
\end{abstract}

\section{Keywords \\ state regulation, education, sustainable development goals, efficiency, national economy, stochastic frontier analysis, reforming}

\section{JEL Classification I26, I28, Q01}

\section{INTRODUCTION}

The sustainable development concept is widely known and attracts the interests of scholars, researchers, policy-makers, and social activists. The analysis of academic citations through the Publish or Perish software had revealed top-cited works. Among the most cited papers in the field of implementing the SDGs, the seminal work of StaffordSmith et al. (2017) should be mentioned. This study is devoted to the conceptualization of the cooperation model between actors under the 2030 Agenda. The scholars and researchers have declared the SDGs system as a new opportunity to create a viable network of countries to integrate the efforts for a common future at a new level (Le Blanc, 2015). Interdisciplinary of the sustainable development concept and its relatedness to the education process was developed in papers of Steiner and Posch (2006) and Arbuthnott (2009). If the first work is about cross-country analysis, the other is accomplished for attitudebehavior relationships at an individual level. However, the issue of ef- 
ficiency of specific systems and branches of the national economy as the subject of study in relatedness to sustainability are less frequent. The 4th SDG expresses the following vision of the desired state in a field of education 'Ensure inclusive and equitable quality education and promote lifelong learning opportunities for all', according to the 2030 Agenda (UN, 2015). The SDGs achievements are at the center of scholars' and practitioners' attention, and there are many papers where debating and conceptualizing sustainable development took place. However, few studies on cross-country analysis combined the evaluation of national economic efficiency, sustainable development progress, and social institutions regulations. In this regard, the study by Lo Storto and Goncharuk (2017) on benchmarking analysis for some European countries' national healthcare systems should be analyzed. The scholars use the non-parametric frontier method based on Data Envelopment Analysis (DEA). In their work, Jikia et al. (2017) presented an approach to assessing the lifelong learning system's financial support in Ukrainian regions through stochastic frontier analysis. Similar studies on the evaluation of efficiency in specific sectors of the national economy are performed by Obeid and Brychko (2017), Kowo et al. (2019), Lambovska et al. (2019), Bercu et al. (2019).

The interlinks between SDG and progress in economies and institutions are at the center of discussions of many scholars (Kostel et al., 2017; Malyarets et al., 2019; Iacobuta et al., 2019; Bhandari \& Bhattarai, 2017; Bhandari \& Shvindina, 2019; Raišiene et al., 2019). However, the institutional influence in a sphere of SDGs achievement is studied fragmentedly, mostly because the number of SDGs is significant, and the scale is global.

\section{LITERATURE REVIEW}

There are at least two dimensions for the literature review in the current study. The first dimension is about how to combine the previous findings on sustainability, regulations in the educational sphere, and methodology evolution in the research field. Another dimension is devoted to analyzing the previous findings in efficiency evaluation.

To start with the complex analysis of multidisciplinary research, the verified techniques and bibliometric measurement were performed. Among existing bibliometric tools, Publish or Perish software is one of the most helpful in identifying seminal, top-cited papers in the domain. Thus, the search using the combination of keywords 'state regulation', 'education', 'efficiency,' and 'sustainable development goals' was accomplished for 2019-2019. The content analysis enabled to select TOP-15 works in research out of the first 200 items ranked by Google Scholar Ranking, as shown in Table 1. Among items, there were books, conference notes, editorials, and papers. For further content analysis, the papers were selected only with a high Google Scholar Ranking (GSR). Notably, the GSR returns outcomes (as 1, 2, 3) in the order of relevance of query results. The cites ranking may result in irrelevant papers, so in this case, three tools were combined as presented further (see Table 1). By doing so, the simplified outcomes of content analysis of selected papers are presented too (see Table 1).

Among the most cited works, the work of MartinezAlier et al. (2010) is worth attention, where the sustainable development paradigm faces the degrowth concept. The comparison between these two flows of thinking made the disadvantages of the latter visible. The challenges in sustainable development should still be discussed in further research, especially in terms of scale and scope, ethical boundaries, technical, economic, and institutional tools.

The study that proves the urgency of radical reorientation in educational policies towards innovative strategies and sustainable development that meets the social needs (Breidlid, 2009) resonates with the study of Khalili et al. (2015) devoted to the role of academia in the promotion and acceleration of sustainable development movement. The researchers accomplished the cross-country survey to understand how cleaner production concepts may infuse academic programs and how to support sustainable development and encourage sustainable education. 
Table 1. The TOP-15 most influential papers in the field of research, ranked by Google Scholar Ranking (GSR), cites, and cites per year (C/pY)

Source: Google Scholar Database search via Harzing's Publish or Perish 7.0 - by the Google Scholar Ranking, and the number of cites and C/pY - for the first round, selecting the relevant papers (excluding books, conference materials, and editorial notes) by content analysis - for the second round.

\begin{tabular}{|c|c|c|c|c|c|c|}
\hline GSR & Cites & $\mathrm{C} / \mathrm{pY}$ & $\begin{array}{c}\text { Year of } \\
\text { publication }\end{array}$ & Authors & Title & Methodology (simplified) \\
\hline 6 & 305 & 101.67 & 2017 & Stafford-Smith et al. & $\begin{array}{l}\text { Integration: the key to } \\
\text { implementing the Sustainable } \\
\text { Development Goals }\end{array}$ & $\begin{array}{l}\text { Conceptualization (key links } \\
\text { identified for the sectors, } \\
\text { countries, and actors) }\end{array}$ \\
\hline 8 & 769 & 153.80 & 2015 & Le Blanc & $\begin{array}{l}\text { Towards integration at last? The } \\
\text { sustainable development goals } \\
\text { as a network of targets }\end{array}$ & $\begin{array}{l}\text { Network analysis based on } \\
\text { interpretations of the wording of } \\
\text { the targets }\end{array}$ \\
\hline 10 & 244 & 61.00 & 2016 & $\begin{array}{l}\text { Costanza, Daly, } \\
\text { Fioramonti, Giovannini, } \\
\text { Kubiszewski, Mortensen, } \\
\text {... and Wilkinson }\end{array}$ & $\begin{array}{l}\text { Modeling and measuring } \\
\text { sustainable wellbeing in } \\
\text { connection with the UN } \\
\text { Sustainable Development Goals }\end{array}$ & $\begin{array}{l}\text { Conceptualization, Sustainable } \\
\text { Wellbeing Index offered }\end{array}$ \\
\hline 13 & 299 & 27.18 & 2009 & Arbuthnott & $\begin{array}{l}\text { Education for sustainable } \\
\text { development beyond attitude } \\
\text { change }\end{array}$ & Review of previous studies \\
\hline 15 & 164 & 32.8 & 2015 & $\begin{array}{l}\text { Khalili, Duecker, Ashton, } \\
\text { and Chavez }\end{array}$ & $\begin{array}{l}\text { From cleaner production to } \\
\text { sustainable development: the } \\
\text { role of academia }\end{array}$ & $\begin{array}{l}\text { Qualitative data collection and } \\
\text { processing (questionnaire), } \\
\text { cross-country }\end{array}$ \\
\hline 25 & 852 & 106.5 & 2012 & $\begin{array}{l}\text { Moldan, Janoušková, and } \\
\text { Hák }\end{array}$ & $\begin{array}{l}\text { How to understand and } \\
\text { measure environmental } \\
\text { sustainability: Indicators and } \\
\text { targets }\end{array}$ & $\begin{array}{l}\text { Critical analysis of contradictories } \\
\text { in targets }\end{array}$ \\
\hline 32 & 135 & 19.29 & 2013 & Yuan and Zuo & $\begin{array}{l}\text { A critical assessment of } \\
\text { the Higher Education For } \\
\text { Sustainable Development } \\
\text { from students' perspectives-a } \\
\text { Chinese study }\end{array}$ & $\begin{array}{l}\text { Qualitative study, students' } \\
\text { awareness of sustainability issues } \\
(1,134 \text { respondents) }\end{array}$ \\
\hline 45 & 142 & 12.9 & 2009 & $\begin{array}{l}\text { L. Simonneaux and } \\
\text { J. Simonneaux }\end{array}$ & $\begin{array}{l}\text { Students' socio-scientific } \\
\text { reasoning on controversies } \\
\text { from the viewpoint of } \\
\text { education for sustainable } \\
\text { development }\end{array}$ & $\begin{array}{l}\text { Qualitative study, students' } \\
\text { reasoning about controversial } \\
\text { socio-scientific issues }\end{array}$ \\
\hline 47 & 265 & 33.13 & 2012 & $\begin{array}{l}\text { Burmeister, Rauch, and } \\
\text { Eilks }\end{array}$ & $\begin{array}{l}\text { Education for Sustainable } \\
\text { Development (ESD) and } \\
\text { chemistry education }\end{array}$ & Conceptualization \\
\hline 78 & 155 & 14.09 & 2009 & Maroy & $\begin{array}{l}\text { Convergences and hybridization } \\
\text { of educational policies around } \\
\text { 'post-bureaucratic' models of } \\
\text { regulation }\end{array}$ & Conceptualization \\
\hline 79 & 185 & 16.82 & 2009 & Breidlid & $\begin{array}{l}\text { Culture, indigenous knowledge } \\
\text { systems and sustainable } \\
\text { development: A critical view of } \\
\text { education in an African context }\end{array}$ & Case study \\
\hline 85 & 709 & 70.90 & 2010 & $\begin{array}{l}\text { Martínez-Alier, Pascual, } \\
\text { Vivien, and Zaccai }\end{array}$ & $\begin{array}{l}\text { Sustainable de-growth: } \\
\text { Mapping the context, criticisms } \\
\text { and future prospects of an } \\
\text { emergent paradigm }\end{array}$ & Conceptualization \\
\hline 142 & 147 & 24.5 & 2014 & Nazarko and Šaparauskas & $\begin{array}{l}\text { Application of DEA method in } \\
\text { efficiency evaluation of public } \\
\text { higher education institutions }\end{array}$ & $\begin{array}{l}\text { A comparative efficiency study } \\
\text { of } 19 \text { Polish universities of } \\
\text { technology }\end{array}$ \\
\hline 194 & 8 & 4.0 & 2018 & $\begin{array}{l}\text { Mohammadalizadehkorde } \\
\text { and Weaver }\end{array}$ & $\begin{array}{l}\text { Universities as Models of } \\
\text { Sustainable Energy-Consuming } \\
\text { Communities? Review of } \\
\text { Selected Literature }\end{array}$ & Review of previous studies \\
\hline 200 & 7 & 0.78 & 2011 & Gorobets & $\begin{array}{l}\text { Corrections to the human } \\
\text { development index and } \\
\text { alternative indicators of } \\
\text { sustainability }\end{array}$ & $\begin{array}{l}\text { Conceptualization, Improvements } \\
\text { for Human Development Index } \\
\text { offered }\end{array}$ \\
\hline
\end{tabular}


Another qualitative study was done later (Yuan \& Zuo, 2013), but for China only. The respondents (1,134 people) were students of educational institutions, and the results showed the level of awareness of sustainability issues in the community. Most Chinese institutions use a top-down approach to incorporate sustainable development. Therefore, the education may offer the optional way of implementing a bottom-up approach and the existing one.

One more qualitative study but narrowed to the case analysis and reasoning was done by French researchers L. Simonneaux and J. Simonneaux (2009). This study has a specificity (ecological niche) and yet brought the findings in the field to the academic community for further discussion.

In the content analysis process, it was revealed that most of the cited papers are devoted to the conceptualization of sustainable development (Maroy, 2009; Gorobets, 2011; Burmeister et al., 2012; Stafford-Smith et al., 2017; Costanza et al., 2016). While forming concepts, researchers offered certain solutions for solving controversialities, for instance, the Sustainable Wellbeing Index (Costanza et al., 2016) or improvements for Human Development Index (Gorobets, 2011). Some papers are remarkably representative in restructuring the findings in the domain (Arbuthnott, 2009; Moldan \& Janoušková, 2012).

There are studies worth mentioning for the literature on interlinks between SDG progress, regulation policies, and education. Governments' intentions to achieve the accepted SDGs are the subject of several scientific discussions (G. Karnitis \& E. Karnitis, 2017; Atkočiūnienė \& Miroshnychenko, 2019). SDGs achievement requires significant changes and reforming and modifications of existing national economic systems (Malyarets et al., 2019; Iacobuta et al., 2019), as well as the institutional components (Bhandari \& Bhattarai, 2017; Bhandari \& Shvindina, 2019; Kostel et al., 2017; Raišienè et al., 2019). Another challenge of transformation is the issues that may appear in a sphere of reproduction of human or intellectual capital (Maslak et al., 2018; Indiyati, 2018; Palascakova et al., 2018), changes in socio-labor relations (Vorontsova et al., 2020a), possible imbalance in education (Zuzeviciute et al., 2017; Tvaronavičienè et al., 2018), etc.
Education is one of the core components of the social sector, and according to numerous theoretical and empirical studies, has a positive impact on the achievements in a sphere of sustainable development through the lens of macroeconomic stability of a country (Palienko \& Lyulyov, 2018; Golovchanskaya et al., 2018), economic growth (Skliar \& Samoilikova, 2014; Rungsrisawat \& Pamornmast, 2019; Vaiciukevičiūte et al., 2019), increasing the level of democracy (Mazurek \& Mielcová, 2019), establishing cooperation and partnerships at the international level (Ulewicz \& Blaskova, 2018; Bondar \& Paszkowski, 2019), development of a lifelong learning system (Kryk, 2016). Existing pressing problems in the field of education, which are usually shared by most of the countries, have been studied by numerous scholars, including Bordean and Sonea (2018), Guziejewska and Majdzińska (2018), Volchik and Maslyukova (2019).

When considering the role and importance of education regulation in modern scientific works, it is recommended to take into account the interests of all stakeholders to ensure a global partnership (Savga et al., 2018; Degtjarjova, Lapina, \& Freidenfelds, 2018; Vorontsova et al., 2020b), to support transparency and quality of educational services, and to guarantee comprehensive and equitable education (Skliar, 2018). Moreover, state regulation should take into account possible public-private partnerships and opportunities to establish them (Eyszczarz, 2016; Kuznetsov et al., 2017; Kohnová et al., 2019), specifics of financing in the industry (Vorontsova et al., 2018) and its marketing (Petrunia et al. 2019) to ensure effective knowledge transfer (Matošková, 2016; Smaliukienè, 2017; Anatan, 2018, Novikova et al., 2020) and sufficient information infrastructure (Wierzbicka, 2018; Polyakov et al., 2019).

Accordingly, the second dimension of the literature review is the comprehensive framework of efficiency evaluation, which is the bottom line of the current research.

According to the Longman Business Dictionary (2000), efficiency is considered a quality that shows "how well an industrial process, factory, or business works so that it produces as much as possible from the time, money, and resources that are 
put into it". Other than that, there is a well-known approach, according to which the efficiency is a "ratio between outcome and costs (resources) to achieve it" (Andriychuk, 2005). Many studies deal with efficiency rather than effectiveness; even if both measure the performance, these terms should be distinguished properly. Detailed research of Mouzas (2006) gave a systematic understanding of similarities and differences of the mentioned terms, and in the current study, the term "efficiency" is used following the logic of DEA (Karlaftis, 2004) as a non-parametric approach to efficiency measurement. On the other hand, the effectiveness is performed at the standard ISO 9000:2015 as "the extent to which planned activities are realized, and planned results are achieved" (ISO 9000:2015, n.d.).

In the opinion of another scholar, Pylypenko (2016), the efficiency may be considered in three dimensions: (a) economic dimension - when the usage of existing resources (natural, financial, human, etc.) are compared to the achieved results; (b) organizational dimension - when the efficiency of management and decision-making system is taken into account; and (c) social - when the costs and resources (input) are compared to the social outcomes or result (i.e., social security, equity, and equality, etc.). These three types of efficiency are related to each other and allow measuring certain object at the microlevel (entity or organization) and the level of country or governance.

In this matter, the study of Nazarko and Šaparauskas (2014) should be mentioned, where the DEA method was implemented for the efficiency evaluation of public higher education institutions. This study encourages searching for a comprehensive toolbox to understand if there is a relationship between educational policies and progress in sustainable development. The mentioned study is less relevant to SDG, but more to the economic and technological efficiency of HEIs performance; still, it showed that the comparison between educational systems of different countries might be representative; therefore, the quantitative study was chosen for current research.

Talking about the efficiency evaluation methods, at least several groups of methods may be distinguished: index methods, which mean that certain aspects or activities may be measured in absolute or relative terms, and they can be performed on average or as an integral index; the expert methods that implies surveys, focus-group, qualitative data collection and data processing, balanced assessment. The next one is econometric methods; they involve more complex econometric analysis models and various analytical tools. Moreover, there are blended methods, which combine the abovementioned. In a broad sense, all the methods of evaluating efficiency can be divided into parametric and non-parametric. For the current study, the parametric method of econometric analysis was chosen to establish the objective function and determine the influence of individual factors on the dependent variable.

Among the great variety of econometric analysis methods, stochastic frontier analysis (SFA) was chosen for several reasons. It allows determining the possible deviations of the actual and potential level of efficiency and receiving optimum value concerning the object of research. This method was first introduced by a group of scientists led by Aigner (Aigner et al., 1977) and was used mainly in production analysis. Later, it began was widely distributed in other fields, as evidenced by the works of Battese and Coelli (1992), Coelli (1996), Farrell (1957), Meeusen et al. (1977), etc.

This method's main essence is to consider a particular situation or entity (in the current case - the country) as a complex system with a set of input parameters and output parameters. In mathematical form, this method of analysis is most often expressed using the production function (Aigner et al., 1977):

$$
Y_{i}=X_{i} \beta+\left(V_{i}-U_{i}\right), i=1 \ldots N,
$$

where $Y_{i}$ is level of benefits of entity (or a producer) $i, i=1, . . N ; X_{i}$ is variable vector of factors for an entity (or a producer) $i ; \beta$ is vector of unknown parameters; $V_{i}$ is standard error; $U_{i}$ is inefficiency index for an entity (or a producer) $i$.

The stochastic frontier analysis needs a so-called efficiency limit to be established for a given situation or entity, mainly in the form of a specific regression dependence. Note that the following formula determines the evaluation of efficiency: 


$$
\left\{\begin{array}{l}
E F_{(i)}=\frac{E\left(Y_{i} \mid U_{i}, X_{i}\right)}{E\left(Y_{i} \mid U_{i}=0, X_{i}\right)}, \\
U_{i}=X_{i} \beta+V_{i}-Y_{i}=\beta_{0}+ \\
+\sum_{j=1}^{n} \beta_{1} \ln \left(x_{i j}\right)+v_{i}-\ln (y),
\end{array}\right.
$$

where $E F_{(i)}$ is the index of technical efficiency of activity of entity $i, E$ is expectation.

It is important to understand that the method outlined above is based on technical efficiency and to distinguish this type of efficiency from others is crucial. For understanding the technical efficiency, the definition of Farrell (1957) who defined it as a firm's success “...in producing maximum output from a given set of inputs" (Farrell, 1957, p. 259) was accepted as initial. The same scholar noted that technical efficiency always, to some extent, reflects the quality of its inputs. Therefore, the following fact should be considered: technical efficiency is measured concerning a given set of parameters (firms), and any dynamic of inputs will affect the outcomes. However, these limitations, according to Farrel (1957), are natural.

However, despite the numerous studies listed above in this area, they remain fragmented; namely, they are either related separately to the educational sphere and the results of its activities or issues of sustainable development and related transformations in the national economy, or efficiency evaluation. Based on this, the current study aims to generalize approaches to define the relationship between the efficiency of the strategy of sustainable development of the national economy and state regulation of education.

\section{RESEARCH METHODS}

At the first stage, the data set is formed. In the current study, identifying independent, additional, and dependent variables and data collection took place. As dependent variables, the unified integral index of SDGs achievements $\left(\mathrm{I}_{\mathrm{SDG}}\right)$ was calculated and, therefore, the progress in implementing the respective strategies in different countries.

The source of data is the World Bank Database (Sustainable Development Goals Data) for 14 coun- tries, namely for Bulgaria (BGR), Belarus (BLR), Czech Republic (CZE), Estonia (EST), Hungary (HUN), Latvia (LVA), Lithuania (LTU), Moldova (MDA), Poland (POL), Romania (ROU), Russian Federation (RUS), Slovakia (SVK), Slovenia (SVN), Ukraine (UKR). The period is 2006-2016.

The integral index calculation method is based on indicative SDGs formed using principal component analysis. Firstly, it provides normalization by comparing initial data with maximum and minimum values (for stimulants and destimulators). Secondly, the components' weight determination takes place according to their correlation proportion and dispersion. Thirdly, the integral index is calculated by the weighing of normalized data. It should be noted that the same algorithm is accomplished for each SDG, and then the integral index for all SDGs achievements is performed.

The second stage is about forming the factors that influence the process of achieving SDGs. In the current study, two groups are considered $-1^{\text {st }}$ group, "Harmonization of the Educational Environment under the State Regulation of Education (HE)," and $2^{\text {nd }}$ group of additional corrective variables that reflect the set of parameters that indicate specialization of a national economy (NEI).

The third stage is about to design an appropriate model based on the parametric method of stochastic frontier analysis and verification of its adequacy. As mentioned earlier, within the SFA framework, the function has a production form and may take many forms depending on specification. The most common is the KobbDouglas function or its complicated version - the translogarithmic function. The reliability and adequacy of the obtained results of performance evaluation depend on the choice of specification. The maximum likelihood ratio test was used to compare the criteria set of the Kobb-Douglas function and the translogarithmic function to select the analysis method.

The calculations were performed via software FRONTIER 4.1. and STATA 11.

The last stage of the study is cluster analysis using the results of parameter values and the interlinks between them. 


\section{EMPIRICAL RESULTS}

The following values of integral indexes were obtained at the first stage and compared for 2006 and 2016 (see Figure 1).

At the second stage, the following components for the groups of variables were offered:

- $\quad 1^{\text {st }}$ group "Harmonization of the Educational Environment under the State Regulation of Education (HE)" is represented by the variables as follows: state funding of education (amount of allocated funds), total education coverage ratio, teacher-student ratio in preschool, primary, secondary and higher education, duration of compulsory schooling;

- $\quad 2^{\text {nd }}$ group of additional corrective variables that reflect the set of parameters that indicate specialization of a national economy (NEI): indicators of change in GDP, GNI, the share of agriculture, industry, and services in the economy, the share of exports and imports of goods and services, and exports of high-tech ICT technologies and services, etc.

The results of the maximum likelihood ratio test are performed further. This method compares the criteria set of the Kobb-Douglas function and the translogarithmic function (see Table 2).

The calculation results proved the necessity of using a translog function (3), which is more flexible and involves various types of dependencies of outcomes on inputs.

$$
\begin{aligned}
& \ln I_{S D G(i)}=\beta_{0}+\beta_{1} \ln \left(H E_{(i)}\right)+\beta_{2} \ln \left(N E I_{(i)}\right)+ \\
& +\beta_{3} \ln \left(H E_{(i)}\right)^{2}+\beta_{4} \ln \left(N E I_{(i)}\right)^{2}+ \\
& +\beta_{5} \ln \left(H E_{(i)}\right) \ln \left(N E I_{(i)}\right)+\left(V_{i}-U_{i}\right), i=1 \ldots N,
\end{aligned}
$$

Table 2. The results of the maximum likelihood ratio test for Kobb-Douglas function and the

\begin{tabular}{|c|c|c|c|c|c|}
\hline Functions & $\begin{array}{l}\text { Log likelihood function } \\
\text { (L) }\end{array}$ & $\chi^{2}$ & LR test & $\lambda$ & Result \\
\hline Kobb-Douglas function (1) & 160,94 & \multirow{2}{*}{9,48} & 88,21 & 0,21 & Declined \\
\hline Translogarithmic function (2) & 349,36 & & 465,04 & 0,99 & Approved \\
\hline Comment & $2>1$ & - & $L R>\chi^{2}$ & $\lambda<\chi^{2}$ & - \\
\hline
\end{tabular}
translogarithmic function (criteria are formed based on Eling and Luhnen (2008))

Source: Authors' calculations via software FRONTIER 4.1.
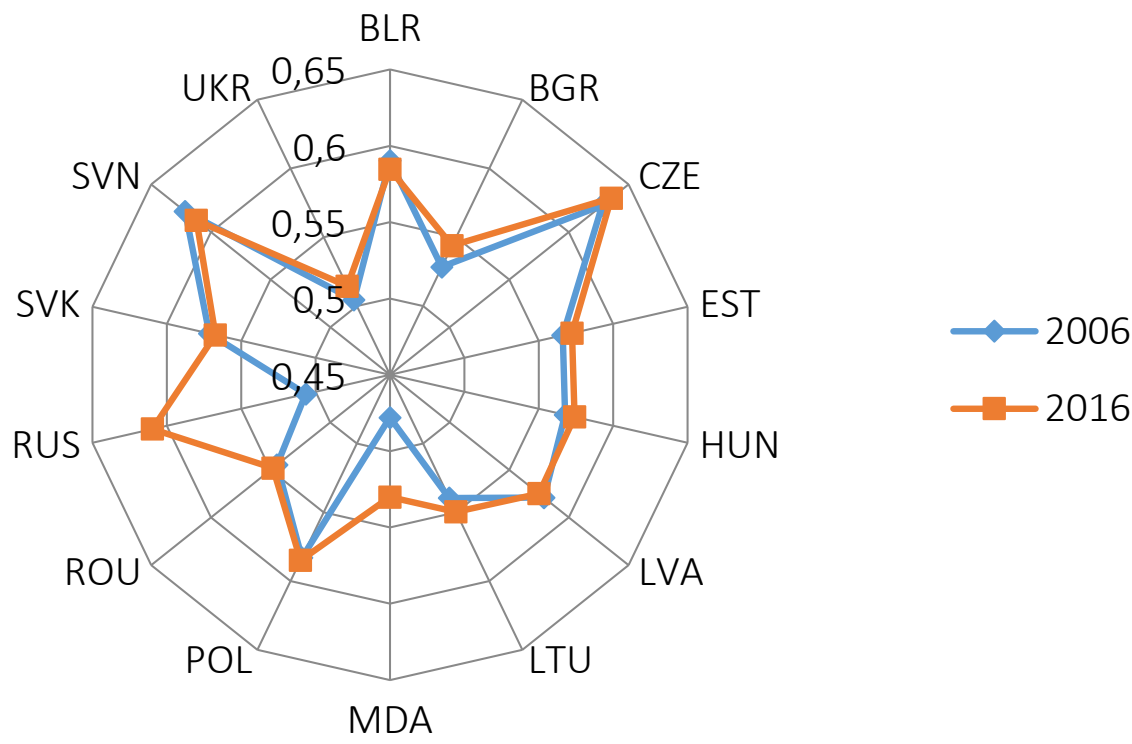

Figure 1. The integral index of SDGs achievements in the sample of Central and Eastern European countries, 2006 and 2016 (based on authors' calculations) 
where $I_{S D G(i)}$ is integral index of SDGs achievements of the $i$-th country; $H E$ is harmonization of the educational environment under the state regulation of education indicators; NEI is specialization of a national economy indicators; $\beta$ is vector of unknown parameters; $U_{i}$ is nonnegative random variables, assumed to account for technical inefficiency; $V_{i}$ is random variables.

The results of the evaluation of the parameters based on the translogarithmic function are presented in Table 3. These calculations describe the relationship between harmonizing the educational environment (HE) and the efficiency of sustainable development strategies implementation in selected countries (NEI).

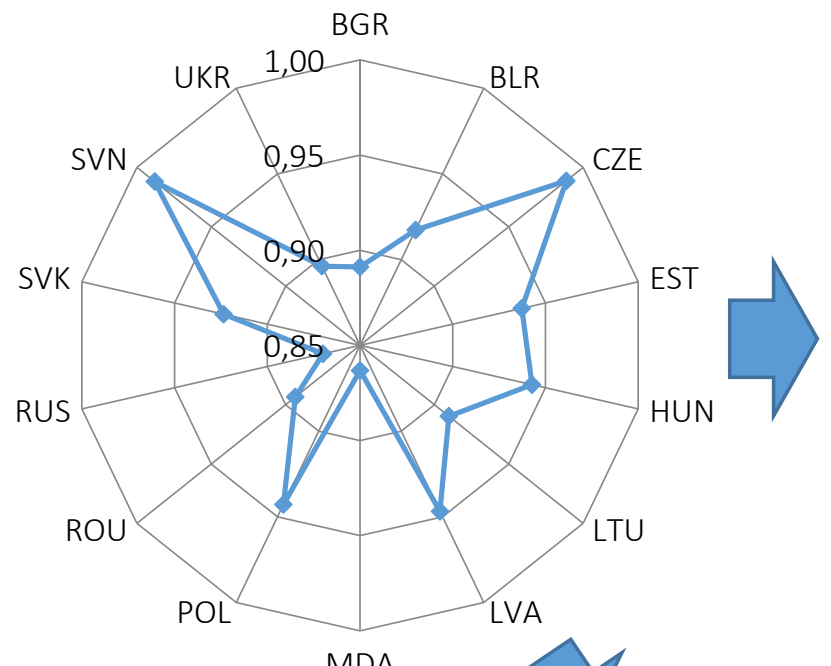

Table 3. Estimation of the translogarithmic function for the identification of a relationship between state regulation of education (HE) and the efficiency of sustainable development strategies implementation (NEI)

\begin{tabular}{c|c|c|c}
\hline Parameter & Coefficient & Standard error & t-statistics \\
\hline$B_{0}$ & 0.673 & 0.021 & 23.103 \\
\hline$B_{1}$ & 0.866 & 0.008 & 9.859 \\
\hline$\delta_{0}$ & 0.179 & 0.036 & 5.235 \\
\hline$\sigma^{2}$ & 0.000 & 0.000 & 2.665 \\
\hline$\lambda$ & 0.999 & 0.000 & 135.506 \\
\hline
\end{tabular}

The evaluation presented above revealed the following dependencies that are adequate and statistically significant:

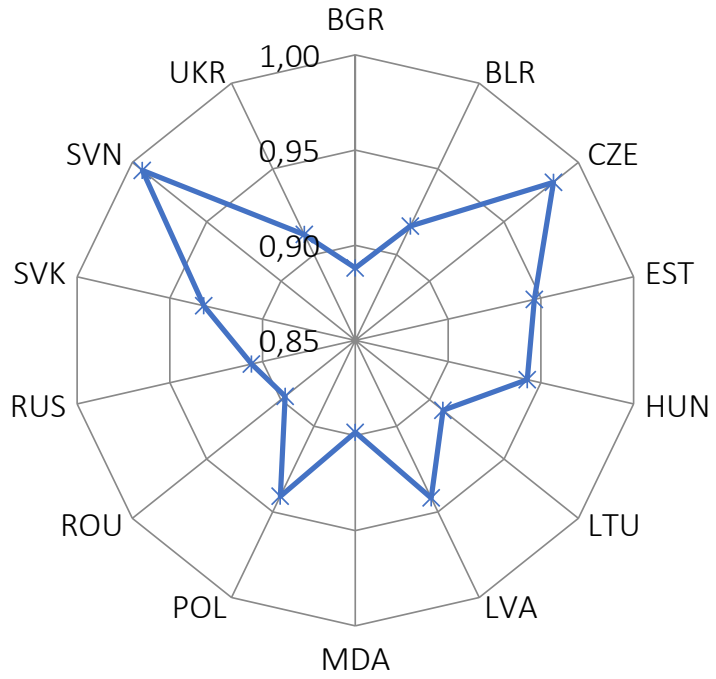

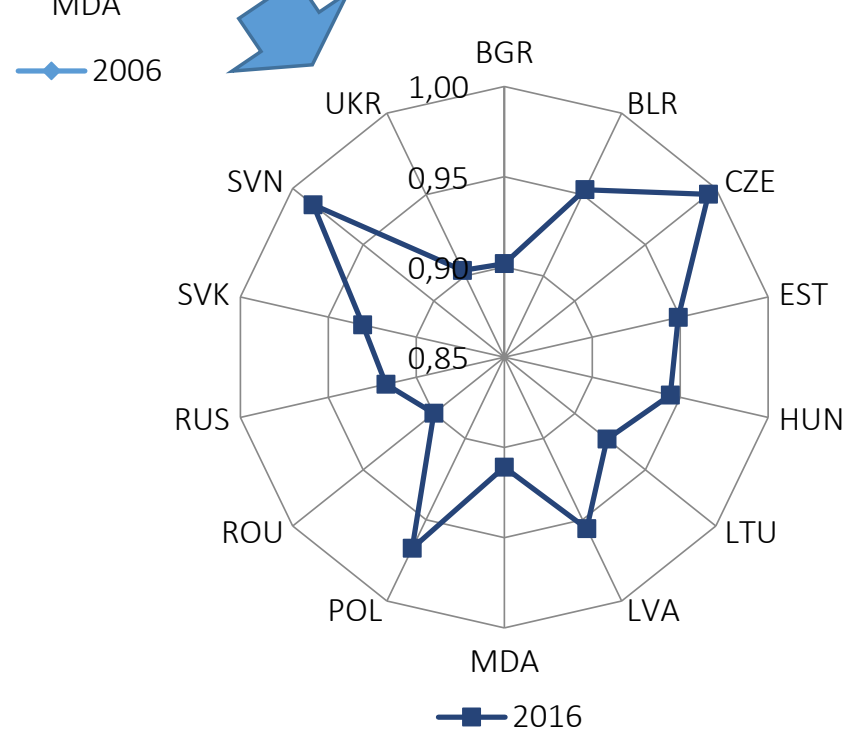

Figure 2. The integral index of efficiency of sustainable development strategy implementations in the sample of Central and Eastern European countries, 2006, 2010, and 2016 (based on authors' calculations) 
- with the growth of the efficiency of state regulation of education, the integral index of achievement of the SDGs will increase by 0.866 ;

- another positive correlation was revealed for sectoral and technological specialization; as the additional parameter increases, the SDGs' achievements integral index will increase by 0.179 .

So far, the results were obtained for the technical efficiency indexes and integral index of efficiency of sustainable strategy development related to the state regulation of education and presented in comparison for 2006, 2010, and 2016 (see Figure 2). The results are between 0.8 and 1.0, indicating the high level and becoming the basis for the cluster analysis for the mentioned countries.

The visual analysis allows identifying leaders of sustainable development strategies implementa- tion in terms of technical efficiency. The leaders are the Czech Republic and Slovenia, and outsiders are Romania and Bulgaria (in 2016). To study the changes of this indicator within the group of analyzed countries, they were divided into three clusters, defining a uniform range of the interval (Table 4).

As a result, the leaders with a high level of influence of state regulation of education on the efficiency of the strategy of sustainable development of the national economy were identified (primarily Slovenia, the Czech Republic, and in 2016 Poland). On the other hand, Ukraine has consistently remained in the first cluster, which shows signs of a low level of efficiency in the implementation of the sustainable development strategy.

In this regard, the main measures to reform the state regulation of education were revealed, which should be taken into account for Ukraine to increase the efficiency of the strategy of sustainable

Table 4. Clusters of Central and Eastern countries distributed by the level of state regulation of education and efficiency of sustainable development strategy implementation

\begin{tabular}{|c|c|c|c|}
\hline Year & $\begin{array}{c}\text { Cluster } \\
\text { identification }\end{array}$ & Quantity & Countries \\
\hline \multicolumn{4}{|r|}{ CLUSTER 1 (LOW LEVEL OF IMPACT) } \\
\hline 2006 & $E_{S D S} \in[0,86 ; 0,91)$ & 5 & Moldova, Russian Federation, Bulgaria, Romania, Ukraine \\
\hline 2008 & $\mathrm{E}_{\mathrm{SDS}} \in[\cdot, 88 ; 0,91)$ & 6 & Moldova, Ukraine, Romania, Bulgaria, Lithuania, Russian Federation \\
\hline 2010 & $E_{S D S} \in[0,89 ; 0,92)$ & 7 & Bulgaria, Romania, Moldova, Russian Federation, Lithuania, Ukraine, Belarus \\
\hline 2012 & $E_{S D S} \in[0,89 ; 0,93)$ & 6 & Bulgaria, Romania, Moldova, Lithuania, Belarus, Ukraine \\
\hline 2014 & $\mathrm{E}_{S D S} \in[0,90 ; 0,93)$ & 6 & Romania, Bulgaria, Ukraine, Moldova, Belarus, Lithuania \\
\hline 2016 & $E_{S D S} \in[0,90 ; 0,93)$ & 7 & Romania, Bulgaria, Ukraine, Moldova, Russian Federation, Lithuania, Slovak Republic \\
\hline \multicolumn{4}{|r|}{ CLUSTER 2 (MIDDLE LEVEL OF IMPACT) } \\
\hline 2006 & $\mathrm{E}_{\mathrm{SDS}} \in[0,91 ; 0,95)$ & 6 & Lithuania, Belarus, Slovak Republic, Estonia, Hungary, Poland \\
\hline 2008 & $E_{S D S} \in[0,91 ; 0,95)$ & 6 & Slovak Republic, Belarus, Estonia, Hungary, Poland, Latvia \\
\hline 2010 & $E_{S D S} \in[0,92 ; 0,96)$ & 5 & Slovak Republic, Poland, Latvia, Hungary, Estonia \\
\hline 2012 & $\mathrm{E}_{S D S} \in[0,93 ; 0,96)$ & 6 & Russian Federation, Slovak Republic, Poland, Hungary, Estonia, Latvia \\
\hline 2014 & $E_{S D S} \in[0,93 ; 0,96)$ & 6 & Slovak Republic, Hungary, Russian Federation, Poland, Estonia, Latvia \\
\hline 2016 & $E_{S D S} \in[0,93 ; 0,96)$ & 4 & Hungary, Estonia, Belarus, Latvia \\
\hline \multicolumn{4}{|r|}{ CLUSTER 3 (HIGH LEVEL OF IMPACT) } \\
\hline 2006 & $\mathrm{E}_{\mathrm{SDS}} \in[0,95 ; 0,99]$ & 3 & Latvia, Slovenia, Czech Republic \\
\hline 2008 & $\mathrm{E}_{\mathrm{SDS}} \in[0,95 ; 0,99]$ & 2 & Czech Republic, Slovenia \\
\hline 2010 & $E_{S D S} \in[0,96 ; 0,99]$ & 2 & Czech Republic, Slovenia \\
\hline 2012 & $\mathrm{E}_{S D S} \in[0,96 ; 0,99]$ & 2 & Czech Republic, Slovenia \\
\hline 2014 & $E_{S D S} \in[0,96 ; 0,99]$ & 2 & Czech Republic, Slovenia \\
\hline 2016 & $E_{S D S} \in[0,96 ; 0,99]$ & 3 & Poland, Slovenia, Czech Republic \\
\hline
\end{tabular}


development of the national economy. The best practices from Poland, Slovenia, and the Czech Republic (the leaders in technical efficiency) are promising for implementations (see Table 5).

Table 5. Guidelines for reforming the system of state regulation of education, using best practices of Poland, the Czech Republic, and Slovenia

\begin{tabular}{|c|c|}
\hline Country & Guidelines \\
\hline \multirow{5}{*}{$\begin{array}{l}\text { Best practices } \\
\text { from Poland }\end{array}$} & $\begin{array}{l}\text { Centralized and decentralized governance } \\
\text { combination }\end{array}$ \\
\hline & Private-public partnership \\
\hline & Development \\
\hline & $\begin{array}{l}\text { Fundraising for the development of education } \\
\text { (i.e., vocational and technical education) }\end{array}$ \\
\hline & $\begin{array}{l}\text { Formal education framework expansion at } \\
\text { state regulation level }\end{array}$ \\
\hline \multirow{3}{*}{$\begin{array}{l}\text { Best practices } \\
\text { from the Czech } \\
\text { Republic }\end{array}$} & $\begin{array}{l}\text { The dominance of decentralized governance } \\
\text { and diversification of the education }\end{array}$ \\
\hline & Autonomy of education institutions \\
\hline & $\begin{array}{l}\text { The legal implementation of digitalization of } \\
\text { education for adults }\end{array}$ \\
\hline \multirow{4}{*}{$\begin{array}{l}\text { Best practices } \\
\text { from Slovenia }\end{array}$} & $\begin{array}{l}\text { Centralized management for secondary, } \\
\text { vocational higher, higher education and } \\
\text { partially adult education }\end{array}$ \\
\hline & $\begin{array}{l}\text { Decentralized management for preschool and } \\
\text { primary education, adult education }\end{array}$ \\
\hline & $\begin{array}{l}\text { The combination of formal and informal } \\
\text { education for adults }\end{array}$ \\
\hline & $\begin{array}{l}\text { Coordination of the state regulation of } \\
\text { education and the Sustainable Development } \\
\text { Goals Program }\end{array}$ \\
\hline
\end{tabular}

Besides the mentioned in Table 5, there are several more promising directions of the reforming. Firstly, one of them is the lifelong learning concept and adult learning development. Another is a privatepublic partnership; for instance, the relationships "Employers - HEIs and stakeholders - Government" can be established in a sustained system. That triad system will generate opportunities in labor markets via contractual and mutually beneficial relationships between employers and educators. It will lead to the creation of new hubs and networks through the innovations boost, direct educational services supply chain, etc. Otherwise, the labor migration will go on and will increase the depopulation crisis in Ukraine. The cooperation between the institutions may be implemented through many forms and models, for instance, known as the coopetition model of institutional partnership, and that can be a direction for further research.

\section{DISCUSSION}

Nevertheless, the study reveals the relationship between the state regulation of education and the sustainable development of the national economy; there are limitations and knowledge gaps to be further investigated. For instance, Switzerland is a leader in green economy development; therefore, sustainable development strategy efficiency is high there, while Scandinavian countries are the leaders in terms of quality of education. The current study focuses on Central and European countries owing to the shared history and similarities of institutions, and for the same reason, the sample is accepted as representative. For the more verified results, the sample of data should be expanded and include the pure leaders in education (Finland) and pure leaders in green innovations (Switzerland) to reveal the patterns. Besides, the stakeholder factors are left beyond the study and components that show transparency and quality of educational services. The challenges in scaling up the transformations in the sphere of sustainable education were addressed but partly, only in a sphere of state regulations. One more aspect should be investigated - the informal education and its influence on the market players' behavior via consulting (Goncharova, 2015) and their sustainability-related practices.

Despite these limitations, the research proved the interlinks between educational policies, educational technologies, ploys and patterns, and sustainable development movement outcomes.

\section{CONCLUSION}

The study confirms the dependence of the efficiency of the strategy of sustainable development of the national economy on the state regulations of education for selected countries of Central and Eastern Europe. As the modeling showed, the harmonization of the educational environment has almost 4.8 times more impact on the efficiency of the strategy of sustainable development of the national economy than the national economy's sectoral and technological specialization. 
The main contribution of the research is formed methodology for cross-country comparison of achievements in the fields of education and sustainable development. Moreover, this study combines the evaluation of national economic efficiency, sustainable development progress, and social institutions regulations indicators.

The empirical results allowed clustering the sample countries and determining the list of measures to reform the system of state regulation of education in Ukraine, depending on the leading countries' experience, taken as a guide. Ukraine, being in the cluster with the lowest level of influence of state regulation of education on the efficiency of the strategy of sustainable development of the national economy, should focus on the insights from the leaders (Poland, Czech Republic, Slovenia), defining features of decentralization of education, developing private-public partnership, stimulating the development of adult education, etc.

The best practices performed in countries-leaders may become a basis for the roadmap of future reform development, which may become a beacon for further research.

By proving the dependence of the national sustainable development strategy's integrated efficiency on the interventions and regulations of government in the sphere of education, the key guidelines for further transformations in Ukraine are justified. One of the most promising directions is a private-public partnership in the field, educational services providers' autonomy, and support of lifelong learning concept and education for adults.

\section{AUTHOR CONTRIBUTIONS}

Conceptualization: Hanna Shvindina.

Data curation: Tetyana Mayboroda, Iryna Heiets.

Formal analysis: Anna Vorontsova, Tetyana Mayboroda.

Investigation: Anna Vorontsova, Tetyana Mayboroda, Halyna Mishenina.

Methodology: Tetyana Mayboroda.

Project administration: Hanna Shvindina.

Software: Anna Vorontsova, Tetyana Mayboroda.

Supervision: Hanna Shvindina.

Validation: Tetyana Mayboroda, Halyna Mishenina, Iryna Heiets.

Visualization: Anna Vorontsova.

Writing - original draft: Hanna Shvindina, Anna Vorontsova, Tetyana Mayboroda, Halyna Mishenina, Iryna Heiets.

Writing - review \& editing: Hanna Shvindina, Anna Vorontsova.

\section{ACKNOWLEDGMENT AND FUNDING}

This research was funded by the grant from the Ministry of Education and Science of Ukraine "Reforming the lifelong learning system in Ukraine for the prevention of the labor emigration: a coopetition model of institutional partnership" (No. 0120U102001).

\section{REFERENCES}

1. Aigner, D. J., Knox Lovell, C. A., \& Schmidt, P. (1977). Formulation and Estimation of Stochastic Frontier Production Function Model. Journal of Econometrics, 6(1), 21-37. https://doi.org/10.1016/03044076(77)90052-5.
2. Anatan, L. (2018). An institutional perspective of knowledge transfer within university and industry alliance. International Journal of Economic Policy in Emerging Economies, 11(4), 378-395. https://doi. org/10.1504/IJEPEE.2018.094519
3. Andriychuk, V. G. (2005). The efficiency of agrarian enterprises activity: theory, methodology, analysis. Kyiv: KNEU.

4. Arbuthnott, K. D. (2009). Education for sustainable development beyond attitude change. International Jour- 
nal of Sustainability in Higher Education, 10(2), 152-163. https://doi. org/10.1108/14676370910945954

5. Atkočiūnienè, Z. O., \& Miroshnychenko, O. (2019). Towards sustainable development: the role of R\&D spillovers in innovation development. Journal of Security and Sustainability Issues, 9(2), 409-419. https://doi.org/10.9770/ jssi.2019.9.2(4)

6. Battese, G. E., \& Coelli, T. J. (1992). Frontier Production Functions, Technical Efficiency and Panel Data: with Application to Paddy Farmers In India. Journal of Productivity Analysis, 3, 153-169. https://doi. org/10.1007/BF00158774

7. Bercu, A.-M., Tofan, M., Cigu, E., \& Petrisor, M.-B. (2019). The Government Effectiveness Drivers and Growth. Empirical evidence from CEE countries. Transformations in Business \& Economics, 18(2A), 553-567.

8. Bhandari, M. P., \& Shvindina, H. (Eds.) (2019) Introduction: The Problems and Consequences of Sustainable Development Goals. In Reducing Inequalities Towards Sustainable Development Goals: Multilevel Approach (pp. 1-25). Denmark: River Publishers. Retrieved from https://www.riverpublishers.com/ book_details.php?book_id=749

9. Bhandari, M. P., \& Bhattarai, K. (2017). Institutional Architecture for Sustainable Development (SD): A Case Study from Bangladesh, India, Nepal, and Pakistan. SocioEconomic Challenges, 1(3), 6-21. http://doi. org/10.21272sec.l.1(3).6-21

10. Bondar, A., \& Paszkowski, J. (2019). Intellectual capital as a factor of cooperation between the countries of the eastern partnership and the european union Polish Journal of Management Studies, 20(1), 78-91. http://doi.org/10.17512/ pjms.2019.20.1.07

11. Bordean, O. N., \& Sonea, A. (2018). Student satisfaction and perceived skills: any link to employability?, Entrepreneurship and Sustainability Issues, 6(1), 356-370. https://doi. org/10.9770/jesi.2018.6.1(22)

12. Breidlid, A. (2009). Culture, indigenous knowledge systems and sustainable development: A critical view of education in an African context. International Journal of Educational Development, 29(2), 140-148. https://doi.org/10.1016/j. ijedudev.2008.09.009

13. Burmeister, M., Rauch, F., \& Eilks, I. (2012). Education for Sustainable Development (ESD) and chemistry education. Chemistry Education Research and Practice, 13(2), 59-68. https://doi.org/10.1039/ C1RP90060A

14. Coelli, T. (1996). A guide to FRONTIER version 4.1: A computer program for stochastic frontier production and cost function estimation (CEPA Working papers, 96/ 07, 33). Retrieved from http://iranarze.ir/ wp-content/uploads/2017/07/7209English-IranArze.pdf

15. Costanza, R., Daly, L., Fioramonti, L., Giovannini, E., Kubiszewski, I., Mortensen, L. F., ... \& Wilkinson, R. (2016). Modelling and measuring sustainable wellbeing in connection with the UN Sustainable Development Goals. Ecological Economics, 130, 350-355. https://doi. org/10.1016/j.ecolecon.2016.07.009

16. Degtjarjova, I., Lapina, I., \& Freidenfelds, D. (2018). Student as stakeholder: "voice of customer" in higher education quality development. Marketing and Management of Innovations, 2, 388-398. http://doi. org/10.21272/mmi.2018.2-30.

17. Eling, M., \& Luhnen, M. (2010). Frontier Efficiency Methodologies to Measure Performance in the Insurance Industry: Overview, Systematization, and Recent Developments. Geneva Pap Risk Insur Issues Pract, 35, 217-265. https://doi. org/10.1057/gpp.2010.1

18. Farrell, M. (1957). The Measurement of Productive Efficiency. Journal of the Royal Statistical Society. Series A (General), 120(3), 253-290. https://doi.org/10.2307/2343100

19. Golovchanskaya, E. E., Strelchenya, E. I., Popkova, E. G., \& Leonenko, O. V. (2018). The key role of intellectual resources in the economic growth models in the institutional environment of innovative activity of the Republic of Belarus: theory and practice. International Journal of Trade and Global Markets, 11(3), 213-227. https://doi.org/10.1504/ IJTGM.2018.095813
20. Goncharova, M. L. (2015). Managerial Consulting in Ukraine: Key Problems, Trends and Development Perspectives. Actual Problems in Economics, 164(2), 136-141.

21. Gorobets, A. (2011). Corrections to the human development index and alternative indicators of sustainability. International Journal of Sustainable Society, 3(2), 107-115. https:// doi.org/10.1504/IJSSoc.2011.039916

22. Guziejewska, B., \& Majdzińska, A. (2018). The model of municipal education expenditures in Poland. Policy, budget and demography. Equilibrium. Quarterly Journal of Economics and Economic Policy, 13(3), 523-541. https://doi. org/10.24136/eq.2018.026

23. Iacobuta, A., Claudiu, M., Mihai, C., Cautisanu, C., \& Cismas, L. (2019). Institutions and sustainable development: a cross-country analysis. Transformations in Business and Economics, 18, 628-647.

24. Indiyati, D. (2018). The role of organisational culture, intellectual capital and competitive advantage in supporting the government policies in education. International. Journal of Economic Policy in Emerging Economies, 11(1/2), 68-82. https://doi.org/10.1504/IJEPEE.2018.091028

25. ISO 9000:2015. (n.d.). Quality management systems - Fundamentals and vocabulary. Retrieved from https://www.iso.org/obp/ ui/\#iso:std:iso:9000:ed-4:v1:en

26. Jikia, G., Vorontsova, A., \& Petrushenko, Yu. (2017). Measuring Efficiency of Financial Support in Lifelong Learning System: A Case Study of Ukrainian Regions. Business Ethics and Leadership, 1(4), 84-92. https://doi.org/10.21272/ bel.1(4).84-92

27. Karlaftis, M. G. (2004). A DEA approach for evaluating the efficiency and effectiveness of urban transit systems. European Journal of Operational Research, 152(2), 354364. https://doi.org/10.1016/S03772217(03)00029-8

28. Karnitis, G., \& Karnitis, E. (2017). Sustainable growth of EU economies and Baltic context: Characteristics and modelling. Journal of International Studies, 10(1), 209-224. 
https://doi.org/10.14254/20718330.2017/10-1/15

29. Khalili, N. R., Duecker, S., Ashton, W., \& Chavez, F. (2015). From cleaner production to sustainable development: the role of academia. Journal of Cleaner Production, 96, 30-43. https://doi.org/10.1016/j. jclepro.2014.01.099

30. Kohnová, L., Papula, J., \& Salajová N. (2019). Internal factors supporting business and technological transformation in the context of Industry 4.0. Business: Theory and Practice, 20, 137-145. https://doi.org/10.3846/btp.2019.13

31. Kostel, M., Leus, D., Cebotarenco, A., \& Mokrushina, A. (2017). The Sustainable Development Goals for Eastern Partnership Countries: Impact of Institutions. SocioEconomic Challenges, 1(3), 79-90. https://doi. org/10.21272sec.1(3).79-90.2017

32. Kowo, Ak. S., Owotutu, S. Ol., \& Adewale, Ad. G. (2019). Enhancing the Operational Effectiveness of Savings and Credit Cooperative Societies for Sustainable Growth. Financial Markets, Institutions and Risks, 3(2), 59-68. http://doi. org/10.21272/fmir.3(2).59-68.2019

33. Kryk, B. (2016). Accomplishment of the European Union lifelong learning objectives in Poland. Oeconomia Copernicana, 7(3), 389-404. https:// doi.org/10.12775/OeC.2016.023

34. Kuznetsov, N., Akopova, E., Panasenkova, T., Przhedetskaya, N., \& Rodionova, N. (2017). Role of clusters and forms of public-private partnership in provision of sustainable growth on the basis of network cooperation within regional innovational system. International Journal of Trade and Global Markets, 10(2/3), 142-150. https://doi. org/10.1504/IJTGM.2017.086073

35. Lambovska, M., Rajnoha, R., \& Dobrovic, J. (2019). From Quality to Quantity and Vice Versa: How to Evaluate Performance in the Budgetary Control Process. Journal of Competitiveness, 11(1), 53-69. https://doi.org/10.7441/ joc.2019.01.04

36. Le Blanc, D. (2015). Towards integration at last? The sustainable development goals as a network of targets. Sustainable Development, 23(3), 176-187. https://doi. org/10.1002/sd.1582
37. Lo Storto, C., \& Goncharuk, A. G. (2017). Efficiency vs Effectiveness: a Benchmarking Study on European Healthcare Systems. Economics and Sociology, 10(3), 102-115. https://doi.org/10.14254/2071789X.2017/10-3/8

38. Longman Business English Dictionary (2000). Efficiency. Retrieved from https://www.ldoceonline.com/ dictionary/efficiency

39. Łyszczarz, B. (2016). Public-private mix and performance of health care systems in CEE and CIS countries. Oeconomia Copernicana, 7(2), 169-185. https://doi.org/10.12775/ OeC.2016.011

40. Malyarets, L., Barannik, I., Sabadash, L., \& Grynko, P. (2019). Modeling the Economic Sustainability of the Macro System (for Example Ukraine). Montenegrin Journal of Economics, 15(3), 23-35. https://doi. org/10.14254/1800-5845/2019.153.2

41. Maroy, C. (2009). Convergences and hybridization of educational policies around 'postbureaucratic'models of regulation. Compare, 39(1), 71-84. https://doi. org/10.1080/03057920801903472

42. Martínez-Alier, J., Pascual, U., Vivien, F. D., \& Zaccai, E. (2010). Sustainable de-growth: Mapping the context, criticisms and future prospects of an emergent paradigm. Ecological Economics, 69(9), 1741-1747. https://doi.org/10.1016/j. ecolecon.2010.04.017

43. Maslak, O., Grishko, N., Vorobiova, K., \& Hlazunova, O. (2018). The optimization of the management mechanism of the intellectual capital of Ukraine. Marketing and Management of Innovations, 1 , 169-183. http://doi.org/10.21272/ mmi.2018.1-12

44. Matošková, J. (2016). Measuring Knowledge. Journal of Competitiveness, 8(4), 5-29. https://doi. org/10.7441/joc.2016.04.01

45. Mazurek, J., \& Mielcová, E. (2019) On the relationship between selected socio-economic indicators and student performances in the PISA 2015 study. E+M Ekonomie a Management, 22, 22-39. https://doi. org/10.15240/tul/001/2019-2-002
46. Meeusen, W., \& Van Den Broeck, J. (1977). Efficiency Estimation from Cobb-Douglas Production Functions With Composed Error. International Economic Review, 18, 435-444. https://doi. org/10.2307/2525757

47. Mohammadalizadehkorde, M., \& Weaver, R. (2018). Universities as Models of Sustainable EnergyConsuming Communities? Review of Selected Literature. Sustainability, 10(9), 3250. https://doi.org/10.3390/ su10093250

48. Moldan, B., Janoušková, S., \& Hák, T. (2012). How to understand and measure environmental sustainability: Indicators and targets. Ecological Indicators, 17, 4-13. https://doi. org/10.1016/j.ecolind.2011.04.033

49. Mouzas, S. (2006). Efficiency versus effectiveness in business networks. Journal of Business Research, 59(10-11), 1124-1132. https://doi. org/10.1016/j.jbusres.2006.09.018

50. Nazarko, J., \& Šaparauskas, J. (2014). Application of DEA method in efficiency evaluation of public higher education institutions. Technological and Economic Development of Economy, 20(1), 25-44. https://doi.or g/10.3846/20294913.2014.837116

51. Novikova, I., Stepanova, A., Zhylinska, O., \& Bediukh, O. (2020). Knowledge and technology transfer networking platforms in modern research universities. Innovative Marketing, 16(1), 57-65. https://doi. org/10.21511/im.16(1).2020.06

52. Obeid, H., \& Brychko, M. (2017). Stakeholder's financial relations and bank business management efficiency: evidence from Ukraine. Financial Markets, Institutions and Risks, 1(2), 12-29. http://doi. org/10.21272/fmir.1(2).12-29.2017

53. Palascakova, D., Kolveková, G., \& Melas, D. (2019). Analysis of State Investments into Human Capital in Slovak Republic. E+M Ekonomie a Management, 22, 114-128. https:// doi.org/10.15240/tul/001/2019-2008

54. Palienko, M., \& Lyulyov, O. (2018). The Impact of Social Factors on Macroeconomic Stability: Empirical Evidence for Ukraine and European Union Countries. SocioEconomic Challenges, 2(1), 103-116. https:// 
doi.org/10.21272/sec.2(1).103-

116.2018

55. Petrunia, Y., Chentsov, V., Życzyński, N., \& Petrunia,V. (2019). Marketing environment and marketing management of universities in Ukraine: national and regional dominants. Innovative Marketing, 15(1), 1-12. https://doi.org/10.21511/ im.15(1).2019.01

56. Polyakov, M., Bilozubenko, V., Korneyev, M., \& Shevchenko, G. (2019). Selection of parameters for multifactor model in the knowledge economy marketing (country level). Innovative Marketing, 15(1), 89-99. https://doi.org/10.21511/ im.15(1).2019.08

57. Pylypenko, S. M. (2016). Theoretical bases of enterprise efficiency estimation. Hlobalni ta natsionalni problem ekonomiky: elektronne naukove fakhove vydannia - Global and national problems of economy: an electronic scientific professional edition, 10, 452-456. (In Ukrainian). Retrieved from http://www.globalnational.in.ua/issue-10-2016

58. Raišienè, A. G., Bilan, S., Smalskys, V., \& Gečienè, J. (2019). Emerging changes in attitudes to interinstitutional collaboration: the case of organizations providing social services in communities. Administratiesi Management Public, 33, 34-56. https://doi.org/10.24818/ amp/2019.33-03

59. Rungsrisawat, S., \& Pamornmast, C. (2019). Does the education, health and employment determine the economic growth: a case study. Journal of Security and Sustainability Issues, 9(2), 701-714. https://doi. org/10.9770/jssi.2019.9.2(26)

60. Savga, L., Krykliy, O., \& Kyrychenko, K. (2018). The Role of Internal and External Stakeholders in Higher Education System in Ukraine. Business Ethics and Leadership, 2(1), 32-43. https://doi.org/10.21272/ bel.2(1).32-43.2018

61. Simonneaux, L., \& Simonneaux, J. (2009). Students' socio-scientific reasoning on controversies from the viewpoint of education for sustainable development. Cultural Studies of Science Education, 4(3), 657-687. https://doi.org/10.1007/s11422-0089141-x
62. Skliar, I. (2018). Towards the assurance of transparency and quality of higher education in Ukraine: National Qualification Framework. Business Ethics and Leadership, 2(1), 96-105. https://doi.org/10.21272/ bel.2(1).96-105.2018

63. Skliar, I. D., \& Samoilikova, A. V. (2014). Risk Evaluation at Enterprise Innovation And Investment Activity Financing. Actual Problems of Economics, 11(161), 173-178. Retrieved from http://nbuv.gov.ua/ UJRN/ape_2014_11_22

64. Smaliukienè, R., Bekešienè, S., Chlivickas, E., \& Magyla, M. (2017). Explicating the role of trust in knowledge sharing: a structural equation model test. Journal of Business Economics and Management, 18(4), 758-778. https://doi.org/10.38 46/16111699.2017.1317019

65. Stafford-Smith, M., Griggs, D., Gaffney, O., Ullah, F., Reyers, B., Kanie, N., \& O'Connell, D. (2017). Integration: the key to implementing the Sustainable Development Goals. Sustainability Science, 12(6), 911-919. https://doi.org/10.1007/ s11625-016-0383-3

66. Steiner, G., \& Posch, A. (2006). Higher education for sustainability by means of transdisciplinary case studies: an innovative approach for solving complex, real-world problems. Journal of Cleaner Production, 14(9), 877-890. https://doi. org/10.1016/j.jclepro.2005.11.054

67. Tvaronavičienè, M., Tarkhanova, E., \& Durglishvili, N. (2018). Sustainable economic growth and innovative development of educational systems. Journal of International Studies, 11(1), 248-256. https://doi. org/10.14254/2071-8330.2018/11$1 / 19$.

68. Ulewicz, R., \& Blaskova, M. (2018). Sustainable development and knowledge management from the stakeholders' point of view. Polish Journal of Management Studies, 18(2), 363-374. https://doi. org/10.17512/pjms.2018.18.2.29

69. United Nations. (2015).

Transforming Our World: The 2030 Agenda for Sustainable Development. New York.

70. Vaiciukevičiūtè, A., Stankevičienè, J., \& Bratčikovienè, N. (2019). Higher education institutions' impact on the economy. Journal of Business Economics and Management, 20(3) 507-525. https://doi.org/10.3846/ jbem.2019.10156

71. Volchik, V., \& Maslyukova, E. (2019). Trust and development of education and science. Entrepreneurship and Sustainability Issues, 6(3), 1444-1455. https://doi.org/10.9770/ jesi.2019.6.3(27)

72. Vorontsova, A. S., Lieonov, S. V., Vasylieva, T. A., \& Artiukhov, A. Y. (2018). Innovations in the financing of lifelong learning system: expenditure optimization model. Marketing and Management of Innovations, 2, 218-231. http://doi.org/10.21272/ mmi.2018.2-18

73. Vorontsova, A., Mayboroda, T., \& Lieonov, H. (2020a). Innovation management in education: impact on socio-labour relations in the national economy. Marketing and Management of Innovations, 3 , 346-357. http://doi.org/10.21272/ mmi.2020.3-25

74. Vorontsova, A., Vasylieva, T., Bilan, Y., Ostasz, G., \& Mayboroda, T. (2020b). The influence of state regulation of education for achieving the sustainable development goals: case study of Central and Eastern European countries. Administratiesi Management Public, 34, 6-26. http:// doi.org/10.24818/amp/2020.34-01

75. Wierzbicka, W. (2018). Information infrastructure as a pillar of the knowledge-based economy - an analysis of regional differentiation in Poland. Equilibrium. Quarterly Journal of Economics and Economic Policy, 13(1), 123-139. https://doi. org/10.24136/eq.2018.007

76. Yuan, X., \& Zuo, J. (2013). A critical assessment of the Higher Education For Sustainable Development from students' perspectives-a Chinese study. Journal of Cleaner Production, 48, 108-115. https://doi. org/10.1016/j.jclepro.2012.10.041

77. Zuzeviciute, V., Praneviciene, B., Simanaviciene, Z., \& Vasiliauskienė, V. (2017). Competence for Sustainability: Prevention of Dis-Balance in Higher Education: The Case of Cooperation While Educating Future Law Enforcement Officers. Montenegrin Journal of Economics, 13, 121130. https://doi.org/10.14254/18005845/2017.13-4.10 